\title{
A Yellowish Granular Lesion in the Esophagus
}

\author{
Seong Keun Lee ${ }^{1}$, Chul Hong Park ${ }^{1}$, Min Hee Jung ${ }^{2}$ \\ Departments of Internal Medicine ${ }^{1}$ and Pathology ${ }^{2}$, Isam Hospital, Busan, Korea
}

Question: A 56-year-old woman visited our hospital for health check-up endoscopy. She had no gastrointestinal symptoms. Her past medical history included diabetes mellitus, hyperlipidemia, and a major depressive disorder. Upper endoscopy revealed a $7 \mathrm{~mm}$-sized yellowish granular lesion in the lower esophagus (Fig. 1A). Upon closer observation, the lesion had multiple tiny granular spots (Fig. 1B). There was no other specific finding in the stomach and duodenum.

What is the most likely diagnosis?

Answer: Histopathologically, Endoscopic biopsy showed numerous foamy histiocytes in the lamina propria of the esophagus (Fig. 2A). On immunohistochemical staining, these cells were strongly positive for CD68 (Fig. 2B), which suggested that these cells originated from histiocytes, characteristic of xanthoma. Therefore, the patient was diagnosed with xanthoma of the esophagus.
Esophageal xanthoma is an extremely rare benign lesion found incidentally in the upper gastrointestinal tract during endoscopy. Twenty-one cases have been reported since it was first reported by Remmele and Engelsing in 1984. ${ }^{1}$ Endoscopically, esophageal xanthoma often manifests as white-to-yellowish, granular elevated lesions or verruciform, that are usually less than $1 \mathrm{~cm}$ in size. The most common location of the lesion is the lower esophagus. ${ }^{2}$ Histopathologically, the lesions consist of clusters of foamy histiocytes in the lamina propria under the squamous epithelium. ${ }^{3}$ A differential diagnosis is needed with other yellowish lesions in the esophagus such as carcinoid tumor, granular cell tumor, or ectopic sebaceous gland. It can be easily missed from a differential diagnosis, because of a very low incidence of esophageal xanthoma, compared with xanthoma of the stomach. Especially, ectopic sebaceous glands in the esophagus are difficult to distinguish from xanthoma by endoscopic findings. The se-
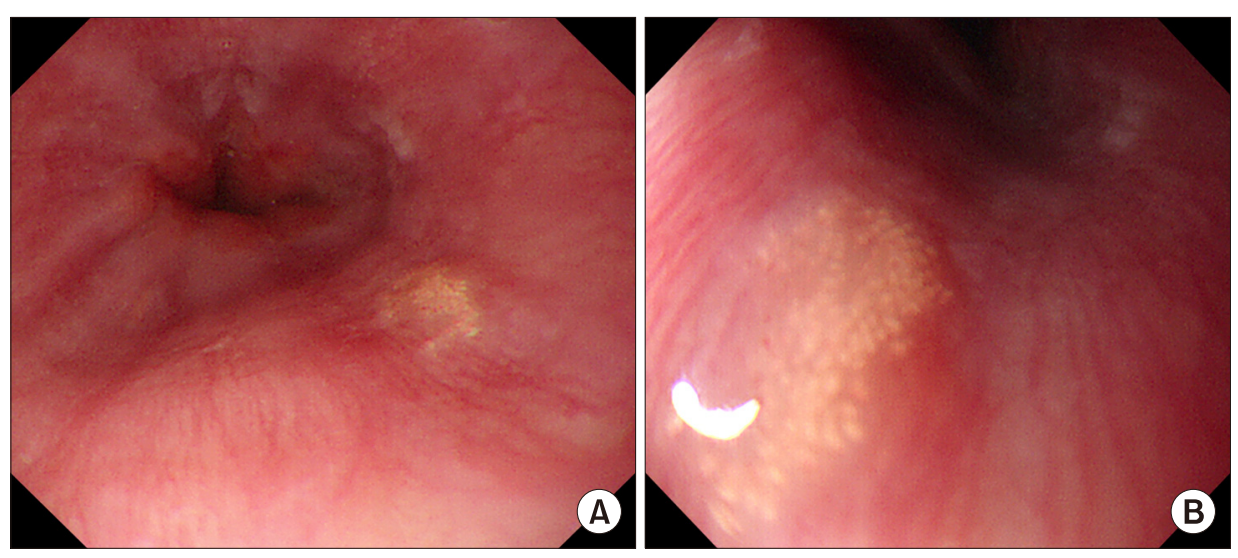

Fig. 1. (A, B) Endoscopy reveals a yellowish elevated lesion with multiple tiny granular spots in the lower esophagus.

Received: August 24, 2017 Revised: October 25, 2017 Accepted: October 29, 2017

Corresponding author: Chul Hong Park

Department of Internal Medicine, Isam Hostiptal, 12 Hwangnyeong-daero, Busanjin-gu, Busan 47354, Korea

Tel: +82-51-631-2110, Fax: +82-51-631-2109, E-mail: doctorparkch@naver.com

Copyright $\odot 2018$ Korean College of Helicobacter and Upper Gastrointestinal Research

() The Korean Journal of Helicobacter and Upper Gastrointestinal Research is an Open-Access Journal. All articles are distributed under the terms of the Creative Commons Attribution Non-Commercial License (http://creativecommons.org/licenses/by-nc/4.0) which permits unrestricted non-commercial use, distribution, and reproduction in any medium, provided the original work is properly cited. 

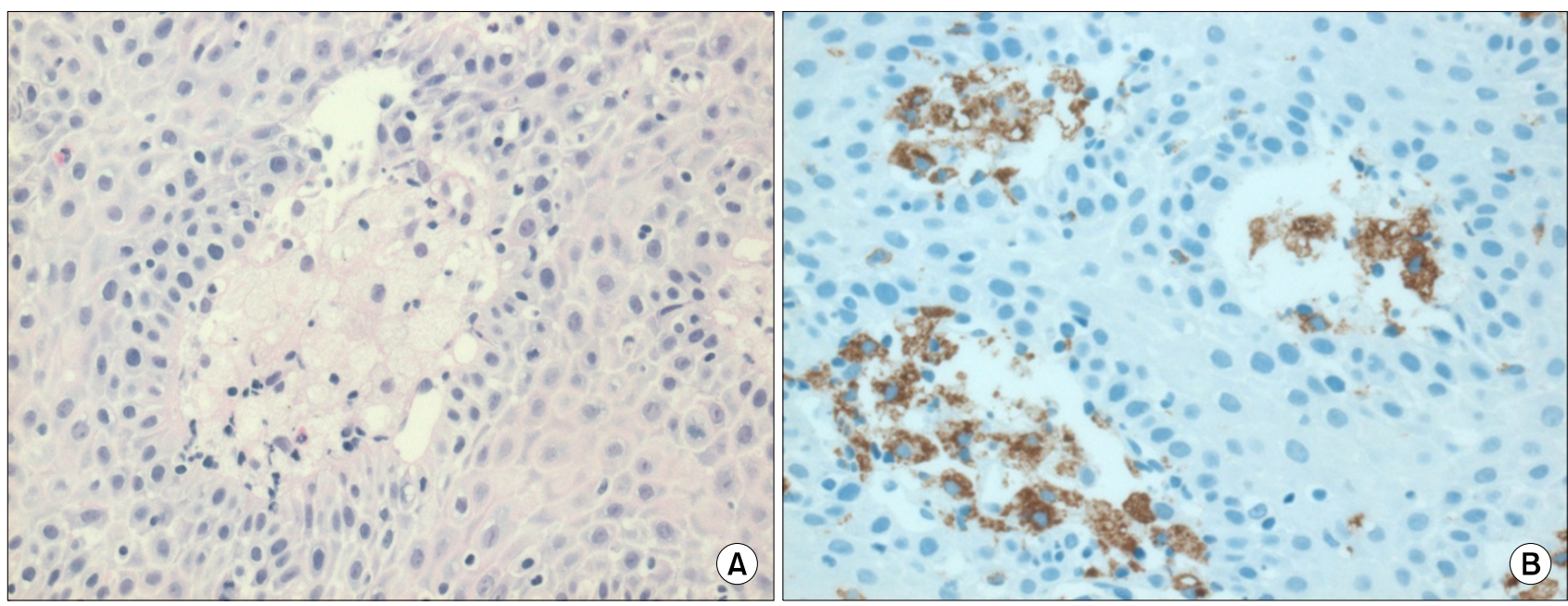

Fig. 2. (A) Endoscopic biopsy shows foamy histiocytes in the lamina propria of the esophagus $(\mathrm{H} \& \mathrm{E}, \times 400)$. (B) On immunohistochemical staining, these cells are strongly positive for CD68 $(\times 400)$.

baceous glands usually have openings and they often cluster compared to xanthoma. ${ }^{4}$

Although the gastric xanthoma is reported to be associated with Helicobacter pylori infection, the pathophysiology and clinical significance of esophageal xanthoma remains unknown. ${ }^{5}$ However, endoscopists need to know the endoscopic findings of the esophageal xanthoma to differentiate small yellowish granular or nodular lesions in the esophagus.

\section{REFERENCES}

1. Dirweesh A, Khan M, Bukhari S, Rimmer C, Shmuts R. Nodular esophageal xanthoma: a case report and review of the literature. Case Rep Gastrointest Med 2017;2017:1503967.

2. Bang CS, Kim YS, Baik GH, Han SH. Xanthoma of the esophagus. Clin Endosc 2014;47:358-361.

3. Kaiserling E, Heinle H, Itabe H, Takano T, Remmele W. Lipid islands in human gastric mucosa: morphological and immunohistochemical findings. Gastroenterology 1996;110:369374.

4. Bertoni G, Sassatelli R, Nigrisoli E, Conigliaro R, Bedogni G. Ectopic sebaceous glands in the esophagus: report of three new cases and review of the literature. Am J Gastroenterol 1994; 89:1884-1887.

5. Gencosmanoglu R, Sen-Oran E, Kurtkaya-Yapicier O, Tozun N. Xanthelasmas of the upper gastrointestinal tract. J Gastroenterol 2004;39:215-219. 